this three months had their origin in very distinct surgical conditions. At the onset, and lasting for a period of from three to fuur weeks, was inability to pass water. I regarded this as belonging to mixed causes-due, on the one hand, to the interruption of so large an extent of the circulation by the application of the ligature, and, on the other hand, to progressive gangrene, both circumstances operating at the same moment of time with combined force to induce sudden and profound nervous shock. The wound, too, exercised an influence, for altbough it was thoroughly antiseptic and closed at the third week-short of a few granulations at its outer extremity-it then suddenly became odematous, whilst rapid swelling about the upper aneurismal sar, and extending helow Prupart's ligament, indicated the diffusion of mischief over a wide space. For six or seven days I was in hesitation as to the proprietig of an incision into some part of this-for I bad little doubt but that I was encountering a suppuration of the sac, so near to which was placed the ligature-when, fortunately, the pus broke alrng the inner end of the wound underneath the healed integument, and found its way in a vast quantity to the granulations, yet keeping open its other end. Great relief followed this occurrence, which was unattended by any blood discoloration save that due to the disturbed granulations. But if this alleviated some of the patient's distress, more especially in regard to the mitigation of the morning perspiration and the loss of appetite, the onward progress of the gangrene speedily renewed their influences. It was very painful to witness the daily emaciation, the loathing for food that was evidently present, added to which there was intolerable pain in the dying limb, assuaged only at nightfall by the subcutaneous use of morphia.

At last came the succour of amputation; and as that proceeding was performed when all gangrene had absolutely ceased, his hopes and his strength began to revive at the moment, and were never arrested by any drawback to the date of his leaving for home, on the 20th of June-five months after the operation,-his stump baving soundly healed, and the aneurismal sacs at Scarpa's point and in the popliteal space being reduced to simple well-defined indurations in the course of the artery.

And now to the story of the ligature. I had naturally felt very auxious that my patient should, if possible, encounter no risk from an inadequate material being used to secure the vessel, and at the same time I could not pass by the importance, when arterial disease appeared so marked, of avoiding cutting through the coats by ulceration, and escaping suppuration. Cer tainly I should not have deemed it right to have suspended every hope of recovery on the hazards of the ordinary catgut, for although I bad myself met with no disaster in the various instances in which $I$ bad secured large veszels in their continuity by such means, I remembered I bad used it only in cases where I had still left me a retreat in case of failure. Here, in a desperate position, I was clearly about to play with a final stake. Under these circumstances I consulted Professor Lister. After one or two trials he sent me the ligature I used, anticipating that whilst it would prove sufficiently enduring to secure the eff ctual closing of the artery, it would be no less capable of complete removal by absorption.

With this, as I have already stated, I tied the vessel by the reef-knot, cutting off both ends close. I never expected to see anything of it again. But it was otherwise. When the suppuration of the sac had ceased I still found the wound at the outer end keeping very slightly open, and on dressing it some eight weeks after the operation, to my great astonishment saw lying on its surface the unaltered noose of the ligature.

On communicating with Professor Lister on the subject, and returning him, for safe keeping, this now historical loop, he writes:-“"The catgut you used had been prepared by a new method, which I have been labouring to perfect, and which I expect very soon to publish; but your case shows that $i t$ is possible to have the catgut, as it.were, too well prepared, so as $t$, remain unabsorbed and also rigid, and in consequence of the latter property liable to make its way out like wire or glass, with or without suppuration"

This incident over, the wound finally closed, so firmiy in deed as to preclude any idea of the probability of bernia.

Here then terminates the mere record of the events of Ihis case.

(To be concluded.)
MANITOU IN COLORA DO (U.S.A.) A HEALTH RESURT IN CONSUMPTION.

B $\mathrm{Y}$ H RM A N W E B R, M.D, F.R.C.P., PHYSICIAY TO THE GRRMAN HOSPITAT.

MaNitou appears as yet to be but little known in Eng. land, although it possesses some special advantages for the English invalid, courterbalancing the disadvantage of the great distance. Having lately had the opportunity of ob. serving the beneficial effect of its climate in several cases, I venture to direct the attention of the profession to it by this short communication, and be 2 to refer for further in. formation to a pamphlet by Mr. Edxin Sully, who is in practice in Manitou, and who is a son of the well-known late surgeon to St. Thomas's Hospital ${ }^{x}$

Manitou, 6370 feet above se 1 level, $38.5^{\circ} \mathrm{N}$. latitude, $105.5^{\circ}$ W. longitude, is situated in a valley on the plateau to the end of the Rocky Mountains, clnse to Pike's Peak (about 14,300 feet high). It is seventy-five miles south of Denver, the capital of Colorado, and five miles west of Colorado Springs, accessible by rail. Altbough Manitou lies in a valley, the hills rise so gradually that they shelter it from wind and dust storms, so injurious $t$, the invalid, without shutting out the sun, which, even on the shortest winter day, shines at least during six hours. Accurate meteoro. logical observations have been made only during a short space of time, but I may assume from numerous reports that the air and soil are remarkably dry, and that the number of clear days is very great, excetding 200 in the year, the remainder being divided between fair and clondy days. Most of the invalids describe the air as eminently exhilarating, and Mr. Solly ascribr's this to a "highly electric condition of the atmosphere." The temperature varies considerably as well at different hours of the same day, as also during different months and seasons of the year. From a table of meteoralngical observations at Colorado Springs (400 feet lower than Maniton), given in Mr. Solly's pamphlet, the figures in the accompanying table are abstracted, the degrees being Fahrenbeit.

The year 1873 has been described to me, I mav add, as exceptionally rich in rain and in snow, the whole amount of other years being in general under thirty inches.

It will be seen from this table that autumn (September, October, November) has the greatest number of clear days (86), with a very moderate heat. The trees being principally cedars and pines, with but scant.y admixture of deciduous foliage, the dampness arising from the decay of fallen leaves is almost imperceptible. This season is to the majority of individuals the most agreeable, bot the winter is protuably the most beneficial to the invalid, compared with other climates. The difference between the night and day and sun and shade temperatures is great but the cold nights do not hurt the patient, who is in-doors, and during the day even the delicate in valid, if warmly clothed, can, according to his condition, sit or walk and ride in the sunshine, the air being mostly calm, owing to the protection of the mountains, and the dryness of the air depriving the cold of its depressing effect. A very intelligent patient of mine, who has become well acquainted with different climates in his long search for health, writes from Manitou Hotel on the last of December, 1876 :- "From the 16 th of October [the day of his arrival at Manitou] to the 23rd of December there were only seven days that were not fine, and the fine days were superb-bright, clear, dry, and exbilarating. Of the seven not fine days I was able to get out to walk on five. The first three weeks of December were uninterruptedly fine. The thermometer in the shade at the north side of the house stond between $50^{\circ}$ and $60^{\circ}$ during the day; on a few unusually warm days it rose to $65^{\circ}$. I was able to sit out in the verandah in the half shade with only a light overcoat on. On the night between the $23 \mathrm{rd}$ and $24 \mathrm{th}$ of December it snowed to the extent of about six inches; the 24th was dull and very cold, the thermo-

1 Manitou, Colorado, U.S.A., its Mineral Waters and Ciimate. BYS, Edwin Solly. Saint Lonis, 1875 . 
meter not rising above $9^{\circ} \mathrm{F}$; the 25 th was quite brighti and fine, but cold, the therm nmeter not going over $30^{\circ} \mathrm{F}$. all day (in the shade); the 26th was snowy again, though not much fell; since then it h+a been quite fine till 1 or 2 ' and overcast afterwards. The weather contiaues cold; the thermometer has generally gone down to zero at night and not teved, but the percussion sound only slightly less sonorous, and the inspiration somewhat feeble, with prolonged expiraticin, and no rhonchi. He had been free from cough for five years, and weighed 10st. $2 \mathrm{lb}$. He said that be had spent, after having left me, six montibs at $J$ iuja, nnd a year and a half between Manitou, Colorado Springs, Denver, and

\begin{tabular}{|c|c|c|c|c|c|c|c|c|c|c|c|}
\hline Moutbs. & & & $\begin{array}{l}\text { Mean, } \\
7 \text { A.M. }\end{array}$ & $\begin{array}{l}\text { Mean, } \\
2 \text { p.M. }\end{array}$ & $\begin{array}{l}\text { Mean, } \\
9 \text { P.M. }\end{array}$ & $\begin{array}{c}\text { Mean of } \\
\text { day. }\end{array}$ & $\begin{array}{l}\text { Cloudy } \\
\text { days. }\end{array}$ & $\begin{array}{l}\text { Fair } \\
\text { days. }\end{array}$ & $\begin{array}{l}\text { Clear } \\
\text { days. }\end{array}$ & Rain. & Snow, \\
\hline December, 1872 & $\ldots$ & $\ldots$ & $\begin{array}{l}\text { Degrees. } \\
17 \cdot 5\end{array}$ & $\begin{array}{l}\text { Degrees. } \\
38 \cdot 5\end{array}$ & $\begin{array}{c}\text { Degrees. } \\
22 \cdot 7\end{array}$ & $\begin{array}{c}\text { Degrees. } \\
26 \cdot 20\end{array}$ & 7 & 3 & 21 & 0.23 & 3.8 \\
\hline January, $1873 \ldots$ & $\cdots$ & ... & $18 \cdot 6$ & $39 \cdot 7$ & 24 & 27 & 一 & 9 & 22 & $0 \cdot 13$ & 0.4 \\
\hline February, $1873 \ldots$ & $\cdots$ & ... & 19 & $42 \cdot 2$ & 2662 & $29 \cdot 27$ & 1 & 10 & 17 & 0.05 & 0.5 \\
\hline March, $1873 \quad \ldots$ & $\cdots$ & $\ldots$ & $31 \cdot 32$ & $55 \cdot 32$ & $39 \cdot 09$ & $41 \cdot 9$ & 2 & 6 & 23 & $0 \cdot 19$ & $0 \cdot 6$ \\
\hline April, 1873 & ... & $\ldots$ & $35 \cdot 23$ & $49 \cdot 92$ & $36 \cdot 66$ & $40 \cdot 61$ & 6 & 7 & 17 & 0.96 & $8 \cdot 3$ \\
\hline May, $1873 \ldots \ldots$ & ... & $\ldots$ & $48 \cdot 03$ & $61 \cdot 94$ & $48 \cdot 15$ & $52 \cdot 84$ & 12 & 7 & 12 & $1 \cdot 76$ & - \\
\hline June, $1873 \ldots \quad \ldots$ & ... & $\ldots$ & $62 \cdot 83$ & $76 \cdot 28$ & $61 \cdot 38$ & $66 \cdot 81$ & 7 & 6 & 17 & $2 \cdot 65$ & - \\
\hline July, $1873 \ldots \quad \ldots$ & ... & ... & $65 \cdot 0$ & $78 \cdot 63$ & $64 \cdot 29$ & $69 \cdot 33$ & 5 & 12 & 14 & 4.53 & - \\
\hline August, $1873 \quad \ldots$ & $\ldots$ & $\cdots$ & $62 \cdot 73$ & $75 \cdot 87$ & $63 \cdot 32$ & $67 \cdot 31$ & 6 & 7 & 18 & $3 \cdot 28$ & 一 \\
\hline September, 1873 & $\cdots$ & $\ldots$ & $52 \cdot 32$ & $60 \cdot 05$ & $54: 6$ & $58 \cdot 65$ & 2 & 4 & 24 & $1 \cdot 70$ & - \\
\hline October, $1873 \quad \ldots$ & ... & ... & $36 \cdot 9$ & $58 \cdot 48$ & $39 \cdot 45$ & $44 \cdot 95$ & 4 & 2 & 25 & 065 & $8 \cdot 7$ \\
\hline November, 1873 & ... & ... & $32 \cdot 02$ & $54 \cdot 08$ & $45 \cdot 27$ & $40 \cdot 46$ & 1 & 2 & 27 & - & - \\
\hline
\end{tabular}

gone over $30^{\circ}$ in the day, but it is quite dry and very exhilarating. I have been able to sit out in the verandab for two or three hours these lagt, days, well wrapped up, in the sun; and a party of gentlemen have gone out riding each day."

Spring is the worst season for an invalid, on account of snow and wind, especially in March and the first part of April, while in the seton 1 half showers are frequent. May brings again pleasant warmth, with little rain, but even in spring there are comparatively few days in which the invalid cannot with due oare spend some time in the open air. The summer is tolerably $h_{\text {irt }}$, hut, owing to the comparative riryness of the air, even delicate persons can, if only the head is well protected, enjoy walking, riding, and driving. The nights are always cool, and there are no mosquitoes. During July and part of August, Mr. Solly states, thunder showers are frequent, buti only of short duration; the sandy soil dries rapidly, and the rir does not produce that feeling of uneasiness and oppression so commonly preceding thunder storms in lower regions. In summer the invalid who can stand a certain amount of fatigue and exposure can ride to the farms higher up in the mountains, or can live in tents at elevations varving from 8000 to 10,000 feet.

This short sketch of the climate of Manitou will show that it has no claim to perfection, but that none of the seasons are so bad as to necessitate removal of the invalid to a distant locality.

The cases to which I have alluded as having come under my personal observation are the following.

1. C. D-, aged twenty-two, a native of New York, belonging to a consumptive family, came to me in August, I868, on account of an attack of hæmoptysis, which had occurred already several times during the preceding three years which be had spent at different places of the Kiviera, at Cairo, and at Algiers, where he had derived benefit for the time, which was lost, again during the spring and sum mer. He was emaciated, weighing only 8 st. $5 \mathrm{lb}$, had dulness and rhonchi over the upper part of the right side, from above the clavicle to the fourth rib in front, and to the middle of the scapula in the back, the left side being likewise not quite free. After the cessation of the bropoptysis, under the inflaence of rest and an emetic, he remuined weak, with a rapid pulse, but free from pyrexia. Under these circumstances $I$ advised him, instead of migrating from one winter health-resort to another, to settle somewhere in an elevated region, and I mentioned specially to him Jauja, in the Peruvian Andes, or the higher reginos of Mexico, or, perhaps, Colorado, of which I then had only heard as a new mountainous region, with a good climare and the opportunity of settling. I had not heard of this gentleman till he consulted me a fortnight ago for some digestive trouble. On examining the chest I found the let $t$ eide perfectiy natural, the upper part of the right side flat- the higher regions of that neighbourhood. He had improved at Jaina, had had congestion of the lungs in the spring of 1869 at L.ma, but no return of bæmoptyeis, and had lost his cough entirely, and gained strength and weight, at Manitou and Colorado. The lungs had given him no trouble since.

2 A. F-, aged twenty-four, a native of California consulted me in 1871 on account of chronic phthisis. He had lost his motser and two brothers from phthisis, and had twice had hæmnptysis in 1868 ; he had spent the winter and spring of 1868-69 at Madeira without loring his cough; he went in the summer of 1869 to Cauterets, and again for the winter and spring to Madeira; in the summer of 1870 he went to Bugrères de Bigorre and Biarri $z$; and in the winter of 1870-71 to Pau. He had, in the beginning of July, 1871, much congh and greenish expectoration, only occasional elevations of temperature, a raher rapid pulse (85 to 95), was emaeiated (9 st. $4 \mathrm{lb}$ ), had dulness and mucous rhonchi over both apices; he felt, very weak, especially in summer, and had no appetite. On the whole, he was better on dry, cold days, and had been betrer in the Pgrenees than at Madeira. I advised this gentleman likewise to seek for a permanent settlement, wirh some occupation, in an elevated part of his own country, California, or in the Peruvian Andes, or in Colorado, advising him outdoor life as much as possible, camping in tents during the summer, if this could be arranged under m+dical superintendence, recommending at the same time frequent meals, with a large proportion of milk. In Decenber, 1871 I heard from this gentleman that he had much improved on the mountains of California during the summer and early autumn, and that he was starting for Colorado for the winter. After an entire silence from that time, A. Fmade his appearance, by a strange coincidence, on the same day with the former gentleman, to introduce a relative, in perfect health himself. After having led an out-door life for nearly three years, including fifteen months at and near Manitou and Denver, he had not only lost bis cougb completely, but had gained 24lb., and had settled near Richmond, in Virginia. The examination of the chest showed only fattening with slight change of percussion sound on the upper part of the left side, with somewhat indistinct inspiration murmurs, and rather loud espiration, but no rhonchi. The right supraclavicular space was likewise less sonorous, hut there were no rhonchi.

I have met with several other persons who have ascribed their recovery to a long stay at Manitou and in the neigh bourbood.

As to the nature of the cases suitable for Mainton, I should say that the cases of chronic catarrbal phtbisis (easts which Niemeyer would have ascribed to chronic catarrbal pnermonia, which Atdison used to call chronic preumonic phthisis), if not too far advanced, would derivo most benefit. 
Individuals who feel better in a dry cool air, who cannot bear great heat, especially moist heat, or dampness in general, whether cold or warm, and those who are apt to feel bilious or sleepless on the seashore, while they feel well on elevated inland places, are particularly suited to a climate like Manitou. Those, on the other hand, who cannot sleep and eat on mountains, while they feel specially well on the seashore, who cannot stand cold even witbout wind or moisture, lose their sleep and appetite in winter, while the great. est summer-heat seems to give them life, increasing their appetite and body-weight, such constitutions ought to avoid mountain health-resorts of great elevation, and select warmer and lower regions. Those, again, whose happiness is intimately bound up with social pleasures, who are fond of great comfort and choice cooking, are, for psychical or social reasons, likewise, as a rule, less adapted to mountain resorts than those who like a certain amount of roughing.

The tendency to hrmoptysis ought to be no obstacle in the majority of cases. I mention this particularly becanse it has often happened to me, and again quite lately, that medical men have objected to elevated regions on account of that supposed tendency to hæmoptysis. I have endeavoured to show on former occasions that this fear is rather imaginary. ${ }^{2}$ On the coast of Peru, where hæmoptysis is frequent, and where it is often the first sign of consumption, the removal to an Andine valley, especially Jauja, between 10,000 and 11,000 feet above sea-level, is regarded as an almost certain cure. Mr. Solly, in a recent letter to me, likewise mentions, as his experience, that the tendency to hremoptysis is by no means increased, but rather checked, by the climate of Manitou, and the two cases mentioned above corroborate his view.

Complication of asthma with chronic phthisis is also by many physicians regarded as forbidding high elevations, but this is not in accordance with my experience. Asthma is set up by such beterogeneous causes that it is rarely poesible to say beforehand which climates will agree with asthmatic patients and which not, but I often come in contact with four different asthmatic persons who feel always best at elevations above 5000 to 7000 feet. The cases which I regard as most unsuitable are the laryngeal class, troublesome every where, but less so at all events in warm and somewhat humid climates.

Careful bygienic and dietetic management is in all climates an essential condition to recovery; time, not reckoned by months, but by years, is always required for the cure of consumption once developed, and Maniton cannot dispense with these conditions, but the whole locality offers opportunity for settling there altogether, and for varying the residence from cooler to warmer, and from higher to less elevated regions. At present there are hotels as well at Manitou as also at Colorado Springs and Denver, which latter, though more exposed to wind, yet possess good qualities for less delicate patients; and higber up in Manitou Park is likewise a tolerable hotel, and still higher in the mountains, between 7000 and 9000 feet, there are farms which give shelter to those who will not camp out in tents.

Grosvenor-street, W.

\section{THREE CASES OF TRAUMATIC TETANUS TREATED WITH CHLORAL HYDRATE; RECOVERY.}

B Y JASPER CARGILL, L.R.C.P. LOND, \&c., GOVWBNMENT MEDICAL OFFICER ST. ANDREW, JAMAICA.

The successful termination of so fatal a disease as traumatic tetanus is of itself a matter of no little interest; out when the physician can, with any shadow of reasoning, ascribe the happy result to medisine, the interest becomes one of deep importance, both to the medical and non-medical public. In submitting the following cases for insertion in The Lancet, I do not think any comments are necessary, inasmuch as the facts speak for themselves.

" On the Treatment of Phthisis by Prolonged Residence in Elevated Regions; Medico-Chirurgical Transactions, 1869, vol. lii., p. 32. On IIsmoptýis as a Cause of Inflammatory Processes and Phthisis; Clinical Society's Transactions, $70 \mathrm{l}$. ii.
While in charge of the Parochial Hospital, St. Thomasin-the-Vale, between the years 1862 and 1868, several cases of trauwatic tetanus came under my care, with the unhappy result of death in every case. The treatinent adopted em. braced opium, Calabar bean, chloroform, Indian hemp, bromide of potassium, \&c. In 1869, I was transferred to the Liguanea plains, St. Andrew, as Government MIedical Officer, since which period I have had four cases of traumatic tetanus to treat. The first of these was that of a jockey, with extensive laceration of the foot and ankle, having been thrown from a horse. The boy got tetanus on tbe fifth day after the injury. He was treated with Calabar bean, with at first well-marked temporary relief, but on the seventh day of the disease he died in great agony. Then came three successful cases, which are briefly as follows.

$\mathrm{C}_{\Delta S E}$ 1.-A constable, aged twenty-eight. Injury : laceration of soft parts of jaw and alveolus, in trying to punch out a decayed tooth with a horseshoe nail. 'This was a very severe case, and several medical men saw it with me. Opistbotonos was so well marked that I was obliged to place pillows under the spine to prevent injury to the neck. Lock-jaw during the first four days rendered it necessary to resort to nutrient enemata. Temperature went as high as $108^{\circ} \mathrm{F}$. The treatment consisted of chloral hydrate, and no other medicine, after clearing out the bowels with calomel and castor oil. The doses varied from ten to thirty grains. The altendants, who witnessed the marked effects of the remedy, knew well when to renew each dose. The man was, in fact, kept constantly under the drug more or less. The active treatment lasted ten days, but for several days during convalescence a spasm would now and then return, which was at once relieved by a dose of chloral.

CASE 2.-A boy, aged seven. Injury: While walking on the grass, barefooted, a large number of cactus thorns broke into the soles of both feet. Tetanus quickly set in. When sent for I was attending a lady in her confinement, but a medical friend saw the case for me the first day, and gave purgative medicine treatment. I extracted as many of the thorns as possible, and applied tallow poultices to feet There was retention of urine in this case, which rendered the use of the catheter occasionally necessary. I gave six grains of chloral hydrate, so as to keep the child under the influence of the drug almost continuously. There was opisthotonos and stiffness about the jaws. The case yielded to treatment in three weeks.

CASE 3.-A white man admitted into my small-pox hospital on December 22nd, 1874, on the fourth day of erup. tion, which proved to be confluent small-pox. His feet became dreadfully sore, and the cast of one came completely away, leaving a raw spongy surface, exceedingly painful. This I dressed with oxide of zinc. On January 6 th, 1875, well-marked tetanus set in, with rigors. The spasms were characteristic and frequent, accompanied with an involuntary noise from the throat, as if the lungs had been suddenly pressed. No lock-jaw, but decided opistho. tonos. Commenced the chloral treatment at once, but the weak condition of the patient rendered it necessary to administer the drug with great caution, and combine a large amount of brandy and ammonia. I thought the case a hopeless one, but on the 10th January the tetanic spasms began to subside, and the raw surface on the feet commenred to heal. The man continued under treatment until the 5th February, having gone through a severe attack of confluent small-pox and tetanus. There is no doubt in my mind that chloral saved his life.

\section{THE HYPODERMIC TREATMENT OF BRONCHOCELE BY ERGOTINE.}

Bx J. G. SINCLAIR COGHILL, M.D., F.R.C.S. EDIN., PHYSICIAN TO THR ROXAL NATIONAL HOSPITAL FOR CONSUYPTION AND DISEASES OF THB CHEST, VENTNOB.

THE therapeutic uses of secale cornutum are being rapidly extended from the comparatively humble and limited rôle to which, in obstetric practice, this drug was originally confined. Its marked influence on the contractile elements of the tissues of the vascular system has led to its being placed in the first rank of hæmostatic remedies. Again, indirectly, from its controlling power over the supply 